\begin{tabular}{|c|c|c|}
\hline & $\begin{array}{l}\text { International Journal of Current Research in } \\
\text { Biosciences and Plant Biology }\end{array}$ & $E=$ \\
\hline & Volume 7 • Number 3 (March-2020) • ISSN: 2349-8080 (Online) & \\
\hline $\begin{array}{l}\text { EXCELLEN } 1 \\
\text { PUBLISHERS }\end{array}$ & Journal homepage: $\underline{w w w . i j c r b p . c o m}$ & \\
\hline
\end{tabular}

\title{
Antibacterial activity, phytochemicals and essential oils in ethyl acetate extract of Cleistopholis patens
}

\author{
A. O. Daniels ${ }^{1 *}$, T. Temikotan ${ }^{1}$ and F. K. Fadairo ${ }^{2}$ \\ ${ }^{1}$ Department of Biological Sciences, Achievers University, Owo, Ondo State, Nigeria \\ ${ }^{2}$ Department of Medical Laboratory Science, Achievers University, Owo, Ondo State, Nigeria \\ *Corresponding author; e-mail: toyosidanny@yahoo.com
}

\begin{tabular}{|c|c|}
\hline Article Info & \multirow{5}{*}{$\begin{array}{l}\text { The ethyl acetate extract of Cleistopholis patens was investigated for its antibacterial } \\
\text { activity against ten bacterial strains and compared with standard antibiotics. The } \\
\text { extract was purified and antibacterial activities were compared with the crude extract. } \\
\text { The multiple antibiotic resistant (MAR) index was determined using known method. } \\
\text { The phytochemical components were examined and the essential oil components were } \\
\text { also investigated using the GC-MS spectra analysis. The antibacterial test revealed the } \\
\text { plant to be active against the test organisms. However, the crude extract showed larger } \\
\text { zones of inhibition compared to the purified extract. The multiple antibiotic resistance } \\
\text { (MAR) index ranged between o.42 and 1.o. The phytochemical analysis revealed the } \\
\text { presence of glycosides, steroids, phenols and tannin. Mineral content of plants are Na } \\
\text { (24.03\%), K (30.14\%), Ca (32.31\%), Mg ( } 26.09 \%) \text {, Zn ( } 28.09 \%), \text { Fe (6.70\%) and Cu } \\
\text { (o.o3\%). The GC-MS analysis showed the presence of essential oils predominantly fatty } \\
\text { acids, sterols, esters, terpenes and alcohols with fatty acid occurring in abundance. The } \\
\text { presence of essential oil in this plant could be responsible for its biological activities and } \\
\text { the result of this work supports the use of the plant in the traditional medicine and } \\
\text { herbal treatment of diseases. }\end{array}$} \\
\hline $\begin{array}{l}\text { Date of Acceptance: } \\
21 \text { February } 2020\end{array}$ & \\
\hline $\begin{array}{l}\text { Date of Publication: } \\
\text { o6 March } 2020\end{array}$ & \\
\hline Keywords & \\
\hline $\begin{array}{l}\text { Cleistopholis patens } \\
\text { Drug resistance } \\
\text { Essential oils } \\
\text { Phytochemicals } \\
\text { Standard antibiotics }\end{array}$ & \\
\hline
\end{tabular}

\section{Introduction}

The search for alternative products and natural phytochemicals isolated from plants used as traditional folkloric medicines is on the increase as so many plants have been studied for activities against pathogens with the aim of developing active drugs against them. Chemical analysis of plant extracts showed the existence of many chemical compounds related to different classes such as alkaloids, quinines, sugar alcohols, terpenes, polyphenols, flavonoids, phenolics and many others. Flavonoids and phenolics and their derivatives are found in most plants. Such compounds are very important for both humans and plants (Dutra et al., 2012) and are often referred to as essential oils.

Essential oils, are complex systems of volatile components and have gained special attention among secondary metabolites because many of them are used as raw materials for the production of perfumes, cosmetics, pharmaceuticals and pesticides. In addition they are exploited in aromatherapy and in phytotherapy. Furthermore they are used as spices and for nutrition (Alviano 
and Alviano, 2009). Volatile oils also have been the sources of natural products and are used for many medical products. They are plant secondary metabolites that are known for their fragrance and food flavor properties. They consist of a complex mixture of mono and sesquiterpenes, phenyl propanoids and oxygenated compounds (Koudou et al., 2005).

Essential oils are complex mixtures of volatile (around $100 \mathrm{u}$ ) to semi-volatile compounds (around $300 \mathrm{u}$ ), usually with a strong odour, rarely colored, soluble in organic solvents but insoluble in water. They comprise volatile compounds of terpenoid and non-terpenoid origin, synthetized through different biosynthetic routes and with distinct primary metabolic precursors. Monoterpenes and sesquiterpenes are usually the main group of compounds found in essential oils. In addition, phenylpropanoids are also very frequent. Moreover, some essential oils may also contain fatty acids and their esters and more rarely nitrogen and sulfur derivatives (Krishnaveni et al., 2014).

The active principles of many drugs found in plants are secondary metabolites. There is therefore, a vital need to investigate plantphytochemical for their major constituents. Cleistopholis patens (Benth.) Engl. and Diels belongs to the family Annonaceae. It is widely distributed in Senegal, Nigeria and Uganda. It is sometimes used as food preservatives (Burkil, 2004). The long narrow leaves held in one plane on slightly drooping branches give this tree a distinctive appearance. The leaves are shiny on their upper surface when fresh. Decoction of the bark is taken to treat stomach ache, diarrhoea, tuberculosis, bronchitis and hepatitis. Bark pulp is applied against swelling, oedema, with low and bark sap is dropped into the nose to treat headache and rubbed in to treat rickets in children. In Uganda, the bark is used in preparation to treat malaria and measles. In Nigeria, the bark is used to treat typhoid fever and menstrual irregularities (Quattara, 2018). The root bark is used as vermifuge, leaf infusion or decoction is administered against hepatitis, fever, trypanosomiasis, and rheumatic arthritis (Atuhe, 2010).

Several Authors have identified some volatile oils from this plant to include (E)-beta-ocimene linalool, (E)- and (Z)-linalool oxides, myrcene, Pcymene, and germacrene D (Ekundayo et al., 1988), a-copaene, $\delta$-cadinene, and germacrene $D$, $\beta$-caryophyllene, germacrene $\mathrm{D}$, and germacrene $\mathrm{B}$ (Boyom et al., 2011), $\beta$-pinene, sabinene, (E)- $\beta$ caryophyllene, (E)- $\beta$-ocimene, germacrene $\mathrm{D}$, apineneand germacrene B, (Quattara et al., 2013). The aim of this study is to challenge the ethyl acetate extract of the stem bark against ten human pathogenic bacteria and also to identify the essential oils isolated from Cleistopholis patens.

\section{Materials and methods}

\section{Collection and identification of plant materials}

Stem bark of Cleistopholis patens was collected from private garden of a traditional healer at Ibode in Ibadan, Oyo State. The plants were identified by Mr. F.O. Omotayo of the Department of Plant Science and Biotechnology, Ekiti State University, Ekiti State. Voucher specimens with voucher numbers WHAE2017/oo1 was deposited in the herbarium of the University. Plant nomenclature and uses are depicted in Table 1. The plant materials were washed with distilled water, air dried at room temperature, milled into powder and kept in sterile containers until use.

\section{Preparation of crude extracts}

The ethyl acetate extracts was prepared by dissolving $200 \mathrm{~g}$ of powdered plant samples in $500 m l s$ solvent. The suspension was allowed to stand for 5 days (120 hrs) at of $32^{\circ} \mathrm{C}$ and then filtered using a sterile muslin cloth and a Whatman No. 1 filter. The collected filtrate was evaporated to dryness under sterile condition at room temperature after which the extracts were kept in sterile bottles until ready for use.

\section{Collection and preparation of microorganisms}

The clinical strains of the test bacteria were obtained from the Department of Microbiology, Obafemi Awolowo University, Ile-ife, Osun State. The organisms were collected and maintained by regular subculturing on nutrient agar. The test organisms were subjected to biochemical test to confirm the authenticity of the organisms. 
Table 1. Plants nomenclature and traditional uses.

\begin{tabular}{llllll}
\hline English name & $\begin{array}{l}\text { Botanical } \\
\text { name }\end{array}$ & Local name & Family & Part used & Traditional uses \\
\hline $\begin{array}{l}\text { Salt and oil tree/ } \\
\text { heartwood }\end{array}$ & $\begin{array}{l}\text { Cleistopholis } \\
\text { patens }\end{array}$ & $\begin{array}{l}\text { Yor; Apako } \\
\text { Ibo; Ojo }\end{array}$ & Annonaceae & Stem bark & $\begin{array}{l}\text { Cough, anthelmintics, } \\
\text { respiratory disease, TB, } \\
\text { purgative }\end{array}$ \\
\hline
\end{tabular}

\section{Sterilization and reconstitution of crude extract}

A five gram portion of the crude extract was reconstituted in 50mL of $25 \%$ dimethyl sulfoxide, the solutionwas sterilized by passing them through millipore membrane filter with pore size $0.45 \mu \mathrm{m}$. The filtrate was then stored in sterile bottles until use.

\section{Standardization of inocula}

One percent (1\%) of solution of sulphuric acid was prepared and mixed properly. Also, $1 \%$ solution of barium chloride was prepared by dissolving $0.5 \mathrm{~g}$ of dehydrated barium chloride $\left(\mathrm{BaCl}_{2} \cdot \mathrm{H}_{2} \mathrm{O}\right)$ in $5 \mathrm{Oml}$ of distilled water. A $0.5 \mathrm{ml}$ aliquot of barium chloride solution was added to $99.5 \mathrm{ml}$ of the sulphuric acid solution and it was the mixed together. The solution was transferred into a capped tube of the same type used for both the control and the test inocula. The solution was kept at temperature of $+4^{\circ} \mathrm{C}$ (Cheesebrough, 2000).

\section{Antibacterial assay of the plant extracts using the agar well diffusion method}

Test organisms were suspended in Nutrient broth and incubated for 4 hours to obtain a concentration corresponding to McFarlands constant $\left(0.5 \times 10^{8} \mathrm{cfu} / \mathrm{ml}\right)$. The inoculum was standardized with the prepared barium sulphate. Sterile Petri dishes were inoculated by the pour plate method. One $\mathrm{ml}(1 \mathrm{ml})$ of the test inoculum was pipetted aseptically into each Petri dish and about $20 \mathrm{ml}$ of sterilized nutrient agar was poured into the inoculated Petri dish.

The agar plates were allowed to set. Wells of $6 \mathrm{~mm}$ diameter were made over the agar plates equidistant from each other using sterile cork borer and $0.5 \mathrm{ml}$ of each plant extracts of different concentrations as prepared by serial dilution were added to the wells using a micropippette. The extracts were allowed to diffuse into the agar for about 20 minutes after which the plates were incubated for $24 \mathrm{hrs}$ at $37^{\circ} \mathrm{C}$. Thereafter, the diameter of inhibition zones formed around each well was measured in $\mathrm{mm}$ and recorded. The experiments were carried out in triplicates and the average values recorded.

\section{Determination of Minimum Inhibitory Concentration (MIC) of plant extracts against test organisms.}

A modified method of Weigand et al. (2008) was adopted in the determination of MIC. The MIC of the extract was determined by diluting the various concentrations with nutrient broth. A $1 \mathrm{ml}$ aliquot of a serial dilution of $100 \mathrm{mg} / \mathrm{ml}, 60 \mathrm{mg} / \mathrm{ml}$, $40 \mathrm{mg} / \mathrm{ml}, 20 \mathrm{mg} / \mathrm{ml}$ and $10 \mathrm{mg} / \mathrm{ml}$ of the extracts was separately added to test tubes containing specifically $0.1 \mathrm{ml}$ of standardized inoculum of 1 to $2 \times 10^{7} \mathrm{cfu} / \mathrm{ml}$. The tubes were incubated aerobically at $37^{\circ} \mathrm{C}$ for $18-24 \mathrm{hrs}$. Two control tubes were prepared for each test batch. This is as follows: tube containing extracts and the growth medium without inoculums (antibiotic control) and the tube containing the growth medium and the inoculums (organism control). The inocula were then plated and inoculated at $37^{\circ} \mathrm{C}$ for $24 \mathrm{hrs}$. The MIC was determined as the lowest concentration of the extracts exhibiting no visible growth (no turbidity) when compared with the control tubes.

\section{Determination of antibiotics sensitivity}

Susceptibility testing using standard antibiotics was carried out using the disk diffusion method of Kirby-Bauer et al. (1966). Standard antibiotics used include; streptomycin $(25 \mu \mathrm{g})$, gentamycin (10 $\mu \mathrm{g})$, erythromycin $(5 \mu \mathrm{g})$, amoxicillin $(25 \mu \mathrm{g})$,

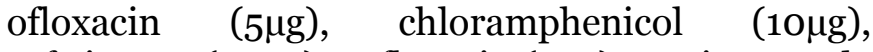
ceftriazone $(30 \mu \mathrm{g})$, pefloxacin $(5 \mu \mathrm{g})$, cotrimoxazole $(25 \mu \mathrm{g})$, ciprofloxacin $(10 \mu \mathrm{g})$, augmentin $(30 \mu \mathrm{g})$, nitrofurantoin $(200 \mu \mathrm{g})$ and tetracycline $(30 \mu \mathrm{g})$. 
Nutrient agar plates were prepared and seeded with bacterial inoculum already standardized with the Macfarland's constant using the pour plate method. After gelling, antibiotic disk were placed on the gelled plate and the plates were incubated at $37^{\circ} \mathrm{C}$ for $24 \mathrm{hr}$ after which the zones of inhibition were observed and recorded.

\section{Multiple Resistance Index:}

The MAR index for the resistant bacterial strains was determined according to the procedure described by Krumperman (1983). This is essentially to determine the degree of bacterial resistance to antibiotics. The indices were determined by dividing the number of antibiotics to which the organisms were resistant to by the number of the antibiotics tested. Resistance to three or more antibiotics is taken as MAR and MAR greater that 0.2 indicates a high risk of multiple antibiotic resistant source of contamination.

\section{Phytochemical screening of plant material}

The plant was screened qualitatively for phytochemicals using the methods of Odebiyi and Sofowora (2005), Evans (2009) and Banso and Ngbede, (2006).

\section{Test for alkaloids}

A $0.2 \mathrm{~g}$ amount of plant extract was acidified with $1 \%$ hydrochloric acid ( $\mathrm{HCl})$ for $2 \mathrm{~min}$ and was then treated with a few drops of Dragendorff's reagent in a test tube. The formation of white precipitate indicates the presence of alkaloids.

\section{Test for saponins}

Sterile distilled water was used to dissolve $0.2 \mathrm{~g}$ of plant extract. A $2 \mathrm{ml}$ amount of the solution was placed in different test tubes and was shaken vigorously for a few minutes. Frothing which persists on warming was taken as an evidence of the presence of saponin.

\section{Test for tannins (Gelatin test)}

To the extract, $1 \%$ gelatin solution containing sodium chloride was added. Formation of white precipitate indicates the presence of tannins.

\section{Test for flavonoids (Shinoda's tests)}

Plant extract was dissolved in $2 \mathrm{ml}$ of dilute $\mathrm{NaOH}$. A yellow solution that turns faint or colourless on addition of a few drops of hydrochloric acid and a change in colour while standing indicates the presence of flavonoids.

\section{Test for cardiac glycosides (Liberman's Test)}

The Liberman's test was used todetermine the presence of cardiac glycosides. A $5 \mathrm{~g}$ amount of plant extract was dissolved in $20 \mathrm{ml}$ of acetic anhydride and cooled with ice. Concentrated $\mathrm{H}_{2} \mathrm{SO}_{4}$ was then carefully added. A colour change from violet to blue and then to green indicated the presence of a steroidal nucleus (a glycone portion of the cardiac glycoside).

\section{Test for steroids (Salkowski test)}

A $0.5 \mathrm{~g}$ portion of plant extract was dissolved in $2 \mathrm{ml}$ of chloroform and $0.2 \mathrm{ml}$ of concentrated $\mathrm{H}_{2} \mathrm{SO}_{4}$ was carefully added to form a layer. A reddish -brown colour ring at the interface between the layers indicated the deoxy- sugar characteristic of cardenolides which indicated the presence of steroids.

\section{Determination of anti-nutrients in plant samples}

\section{Preparation of fat free samples}

A $2 \mathrm{~g}$ amount of each sample were defatted with $100 \mathrm{ml}$ of diethyl ether using a Soxhlet apparatus for $2 h$, and then used for the determination of antinutrients. Alkaloids and cyanogenic glycosides were determined by the gravimetric precipitation method as described by (Harbone, 1984).

Flavonoids and anthocyanins were determined following the method of Boham and KocipaiAbyazan (1994). While tannin was determined by the Folin-Dennis spectrophotometric method as described by Blainski et al. (2013). Spectrophotometric methods as described by Obadoni and Ochuko (2002) were used to determine the saponin content. 


\section{Determination of mineral content of plants samples}

Mineral was estimated by the used of an Atomic Absorption Spectrophotometer. The sample solutions in the sample bottles were analyzed for the concentration of the individual elements. Each element has specific cathode discharge lamp and this lamp was used to determine a particular element. Discharge lamp emits radiation at a wavelength specific for each element being assayed. This specificity can be obtained only from a pure sample of the element that is excited electrically to produce an arc spectrum on that element.

\section{Bioassay guided fractionation of plant extracts (purification)}

Fractionation of the crude extract of $C$. patenswas carried out using the methods of Cosa et al. (2006).

\section{Purification of crude extracts}

The ethyl acetate fractions were allowed to run through a short column and the fractions were collected, and the thin layer chromatography was carried out to ascertain the purity of the compounds.

\section{Antibacterial assay of purified fractions}

Fractions from column chromatography were subjected to bioassay to determine the active fraction using the disk diffusion method of KirbyBauer et al. (1966). as described above.

\section{Gas Chromatography and Mass spectra (GC-MS) analysis of purified fractions}

Ethyl acetate extracts of Stem bark of $C$. patens were analyzed with the help of GC-MS analyzer (Perkin Elmer Gas Chromatography- Mass Spectrum). On Elite-1 column the date was generated. The carrier gas helium (99.999\%) was used at flow rate of $1 \mathrm{ml}$ per min in split mode (10:1). $8 \mu$ of sample was injected to column at $250^{\circ} \mathrm{C}$ injector temperature. Temperature of oven starts at $60^{\circ} \mathrm{C}$ and hold for $6 \mathrm{~min}$ and then it was raised at rate of $10^{\circ} \mathrm{C}$ per min to $300^{\circ} \mathrm{C}$ without holding. Holding was allowed for $6 \mathrm{~min}$ at program rate of $5^{\circ} \mathrm{C}$ per min. Temperature of ion sources was maintained at $240^{\circ} \mathrm{C}$. The injector temperature was set at $250^{\circ} \mathrm{C}$ and detector temperature was set at $260^{\circ} \mathrm{C}$. The mass Spectrum of compounds present in samples was obtained by electron ionization at $70 \mathrm{eV}$ and detector operates in scan mode 50 to $600 \mathrm{Da}$ atomic units. A 0.5 seconds of scan interval and fragments from 50 to $600 D a$ was maintained. Total running time was 40 minutes.

\section{Results}

Table 2 shows the antibacterial activity of extract of C. patens against test bacteria in comparison with standard antibiotics. The M100 of the CLSI (2017) was used to interpret the antibiotic test result. Pseudomonas aeruginosa was resistant to the extract of $C$. patens, and some of the standard antibiotics including, augmentin, ciprofloxacin, nitrofurantoin, gentamycin cotrimoxazole and amoxicillin while it was sensitive to ofloxacin with a zone of inhibition of $18 \mathrm{~mm}$, ciprofloxacin $(12 \mathrm{~mm})$, tetracycline $(16 \mathrm{~mm})$ and pefloxacin (12mm).

Salmonella typhi was sensitive to the plant extract with zones of inhibition of $14 \mathrm{~mm}$ but resistant to the standard antibiotics used. Escherichia coli was resistant to the plant extract but sensitive to gentamycin $(30 \mathrm{~mm})$, cotrimoxazole $(22 \mathrm{~mm})$ and pefloxacin (24mm).

Proteus vulgaris was sensitive to the plant extract with a zone of inhibition of $22 \mathrm{~mm}$ but resistant to all antibiotic disks except pefloxacin (24mm). Streptococcus pyogenes was sensitive to the plant extract with a zone of inhibition of $18 \mathrm{~mm}$, Nitrofurantoin $(14 \mathrm{~mm})$, gentamycin $(14 \mathrm{~mm})$, and cotrimaxazole $(14 \mathrm{~mm})$. Klebsiella aerogenes was sensitive to the plant extract but resistant to all antibiotics disks used. Staphylococcus aureus was sensitive to the plant extract $(14 \mathrm{~mm})$, gentamycin $(28 \mathrm{~mm})$ and ofloxacin $(28 \mathrm{~mm})$.

Escherichia coli was resistant to plant extract and some of the antibiotics but sensitive to gentamycin $(30 \mathrm{~mm})$, cotrimoxazole $(22 \mathrm{~mm})$ and pefloxacin $(24 \mathrm{~mm})$. Streptococcus pyogenes was sensitive to the test extract $(18 \mathrm{~mm})$, nitrofurantoin $(14 \mathrm{~mm})$, gentamycin $(14 \mathrm{~mm})$ and cotrimoxazole $(14 \mathrm{~mm})$. 
Table 2. Antimicrobial susceptibility of test bacteria.

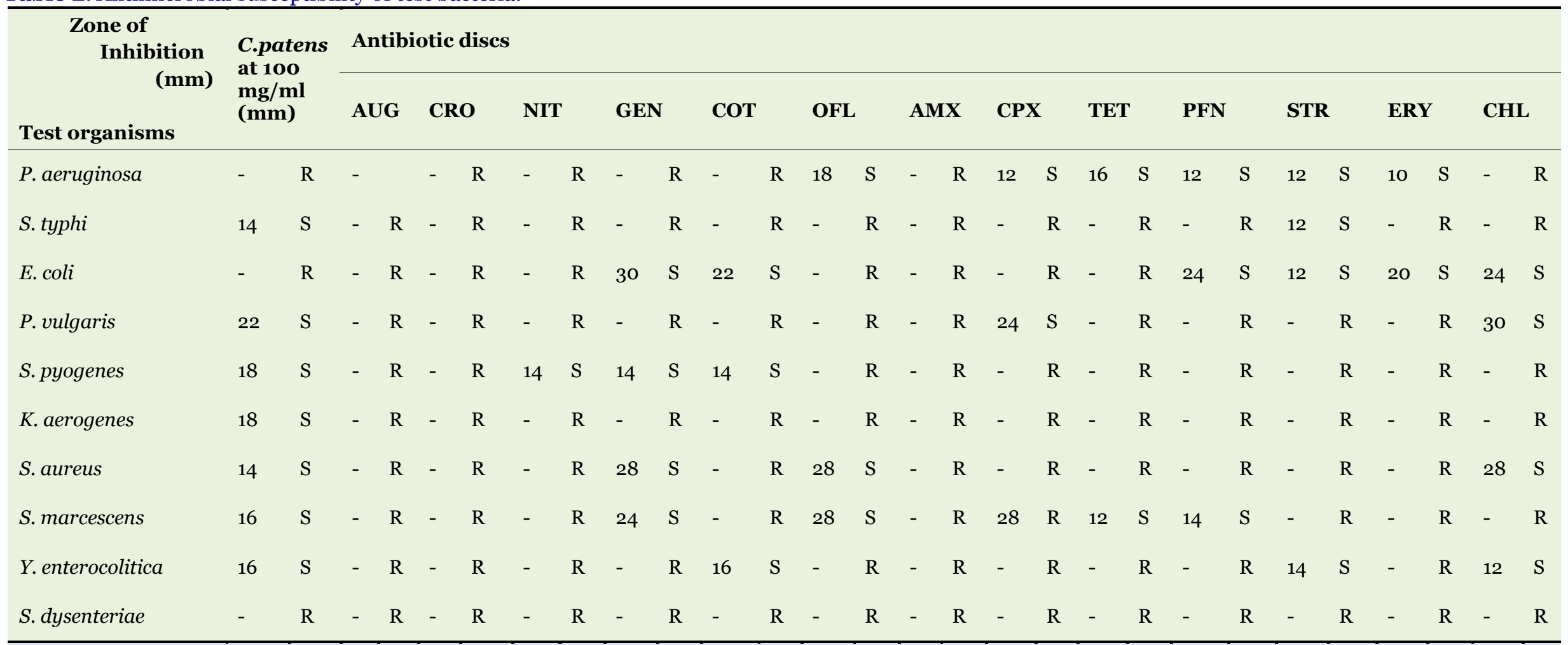

Antibiotics: AUG- Augmentin, CRO- Ciprofloxacin, NIT- Nitrofurantoin, GEN- Gentamycin, COT- Cotrimoxazole, OFL- Oflaxacin, AMX-Amoxycillin, CPX.Ciprofloxacin, TET-Tetracycline, PFN- Pefloxacin; - = No inhibition; R = Resistant; S = Susceptible. 
Staphylococcus aureus was sensitive to the plant extract $(14 \mathrm{~mm})$, gentamycin $(28 \mathrm{~mm})$ and ofloxacin $(28 \mathrm{~mm})$. Serratia marcescens was sensitive to the plant extract $(16 \mathrm{~mm})$, gentamycin (24), ofloxacin $(28 \mathrm{~mm})$, ciprofloxacin $(28 \mathrm{~mm})$ tetracycline (12mm) and pefloxacin (14mm).

Yersinia enterocolitica was sensitive to the plant extract $(16 \mathrm{~mm})$ and cotrimoxazole $(16 \mathrm{~mm})$ while Shigella dysenteriae was resistant to all antimicrobials including the plant extract used.

\section{MAR Index}

The MAR (multiple antibiotic resistance index) of each test bacteria is as listed in Table 3. All test bacteria had MAR index greater than 0.2 indicating that all test organisms have a multiple drug resistant factor.

\section{Minimum inhibitory concentrations of Cleistopholis patens against test organisms}

The MIC values of the plant extracts against test organisms are represented in Fig 1. The minimum inhibitory concentration of ethyl acetate extract against $S$. aureus was $40 \mathrm{mg} / \mathrm{ml}, Y$. enterocolitica was $40 \mathrm{mg} / \mathrm{ml} S$. typhi, $S$. pyogenes, $K$. aerogenes was $20 \mathrm{mg} / \mathrm{ml}, P$. vulgaris was $20 \mathrm{mg} / \mathrm{ml}$. Other bacteria were resistant to the plant extract.

Table 3. Multiple antibiotic resistance index of test bacteria.

\begin{tabular}{ll}
\hline Test bacteria & MAR index \\
\hline P. aeruginosa & 0.47 \\
S. typhi & 0.92 \\
E. coli & 0.67 \\
P. vulgaris & 0.85 \\
S. pyogenes & 0.77 \\
K. aerogenes & 1 \\
S. aureus & 0.77 \\
S. marcescens & 0.69 \\
Y. enterocolitica & 0.77 \\
S. dysenteriae & 1.0 \\
\hline
\end{tabular}

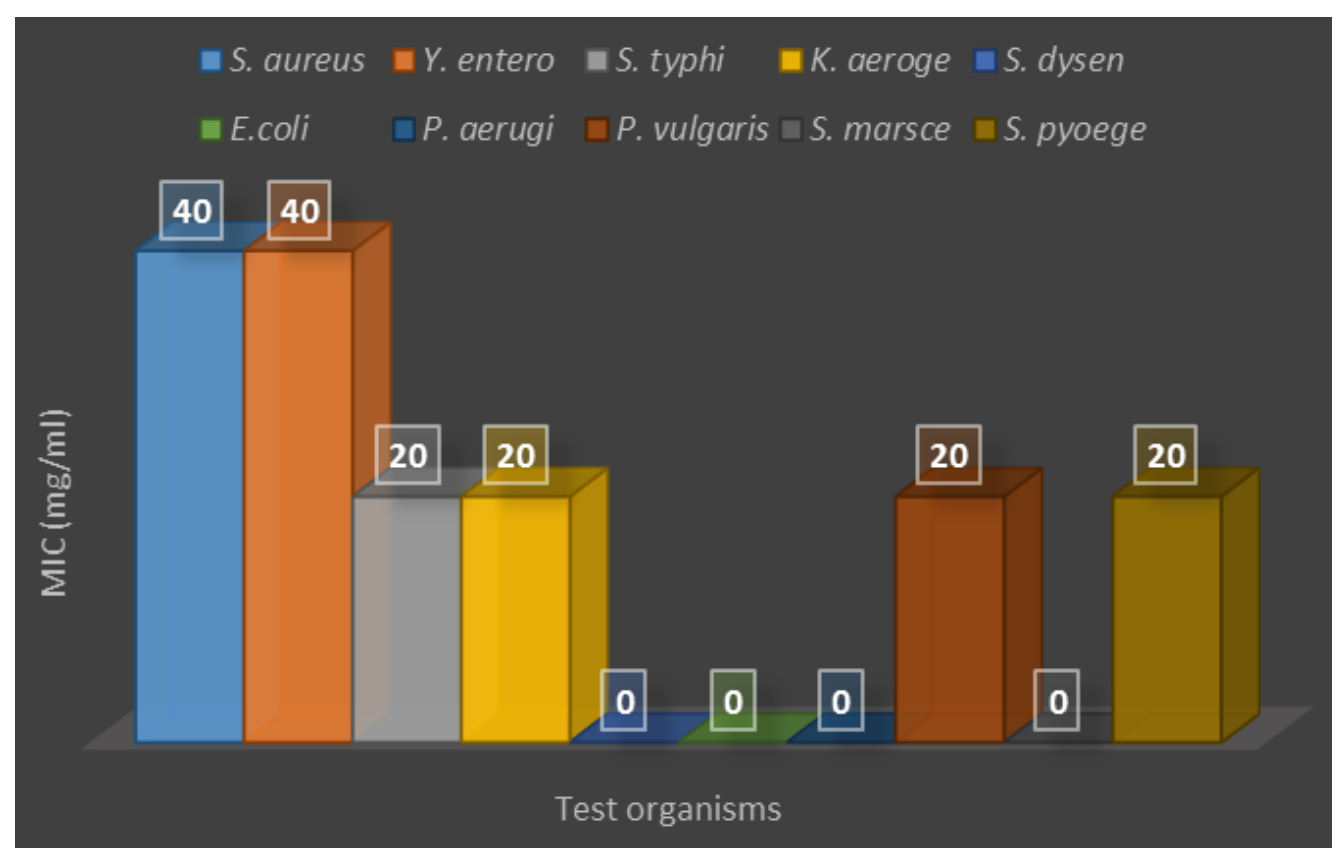

Fig. 1: MIC values of plant extract against test organisms. 
The antibacterial test result of purified fraction is presented in Table 4. The $\mathrm{Cp} 7$ fraction was active against $P$. vulgaris $(7 \mathrm{~mm}), S$. aureus $(6 \mathrm{~mm}), S$. pyogenes $(6 \mathrm{~mm}), K$. aerogenes $(14 \mathrm{~mm}), S$. typhi $(6 \mathrm{~mm})$ and $Y$. enterocolitica $(8 \mathrm{~mm})$. Fraction $\mathrm{Cp}_{12}$ was active against $P$. vulgaris $(12 \mathrm{~mm}), S$. aureus (10mm), S. pyogenes $(9 \mathrm{~mm}), K$. aerogenes $(12 \mathrm{~mm}), S$. typhi $(8 \mathrm{~mm})$ and $Y$. enterocolitica $(8 \mathrm{~mm})$. Cp $12_{3}$ was active against $P$. vulgaris $(8 \mathrm{~mm}), S$. aureus $(8 \mathrm{~mm}), S$. pyogenes $(8 \mathrm{~mm}), K$. aerogenes $(6 \mathrm{~mm}), S$. typhi $(6 \mathrm{~mm})$, but no activity against $Y$. enterocolitica.

Table 4. Antibacterial activity of the purified fractions of Cleistopholis patens.

\begin{tabular}{|c|c|c|c|c|c|c|c|c|c|c|c|c|c|c|}
\hline \multirow{3}{*}{ Fraction } & \multirow{3}{*}{$\begin{array}{l}\text { Colour of } \\
\text { fraction }\end{array}$} & \multirow{3}{*}{$\begin{array}{l}\mathbf{R}_{\mathbf{f}} \\
\text { value }\end{array}$} & \multicolumn{12}{|c|}{$\begin{array}{l}\text { Antimicrobial test of purified extracts } \\
\text { (organisms and zones of inhibition in } \mathbf{m m} \text { ) }\end{array}$} \\
\hline & & & \multicolumn{2}{|l|}{ PV } & \multicolumn{2}{|l|}{ SA } & \multicolumn{2}{|l|}{ SP } & \multicolumn{2}{|c|}{ KA } & \multicolumn{2}{|l|}{ ST } & \multicolumn{2}{|l|}{$\mathbf{Y E}$} \\
\hline & & & $\mathrm{Cr}$ & $\mathbf{P u}$ & $\mathrm{Cr}$ & $\mathbf{P u}$ & $\mathrm{Cr}$ & $\mathbf{P u}$ & $\mathrm{Cr}$ & $\mathbf{P u}$ & $\mathrm{Cr}$ & $\mathbf{P u}$ & $\mathrm{Cr}$ & $\mathbf{P u}$ \\
\hline $\mathrm{CP}_{7}$ & Dark brown & 0.083 & 22 & 7 & 14 & 6 & 16 & 6 & 16 & 8 & 14 & 6 & 16 & 8 \\
\hline
\end{tabular}

\section{Phytochemical constituents of Cleistopholis patens}

The qualitative analysis of Cleistopholis patens showed the presence of glycoside, steroid, phenol, tannin and saponin. Alkaloid and anthraquinone were not detected while the quantitative analysis showed Tanin (2.20\%), phenol (3.50\%), phylate (17.30\%), oxalate (3.69\%), saponin (13.89\%) flavonoid (9.89\%).The mineral content of $C$. patens include $\mathrm{Na}$ (24.03\%), K (30.14\%), Ca (32.31\%), Mg (26.09\%), Zn (28.09\%), Fe (6.70\%),
$\mathrm{Cu}(0.03 \%)$ while lead $(\mathrm{Pb})$ was not detected.

\section{GCMS Spectra of Cleistopholis patens fractions}

GCMS analysis of the sample contained 12 compounds that matched NIST library data. The spectra revealed the presence of predominantly a Pinene, Beta- Pinene, Azulene, Terpinolene, oxypurinol, fatty acids and esters. The identified compounds and quantities are listed in Table 5 and the spectra plate is presented in Fig. 2.

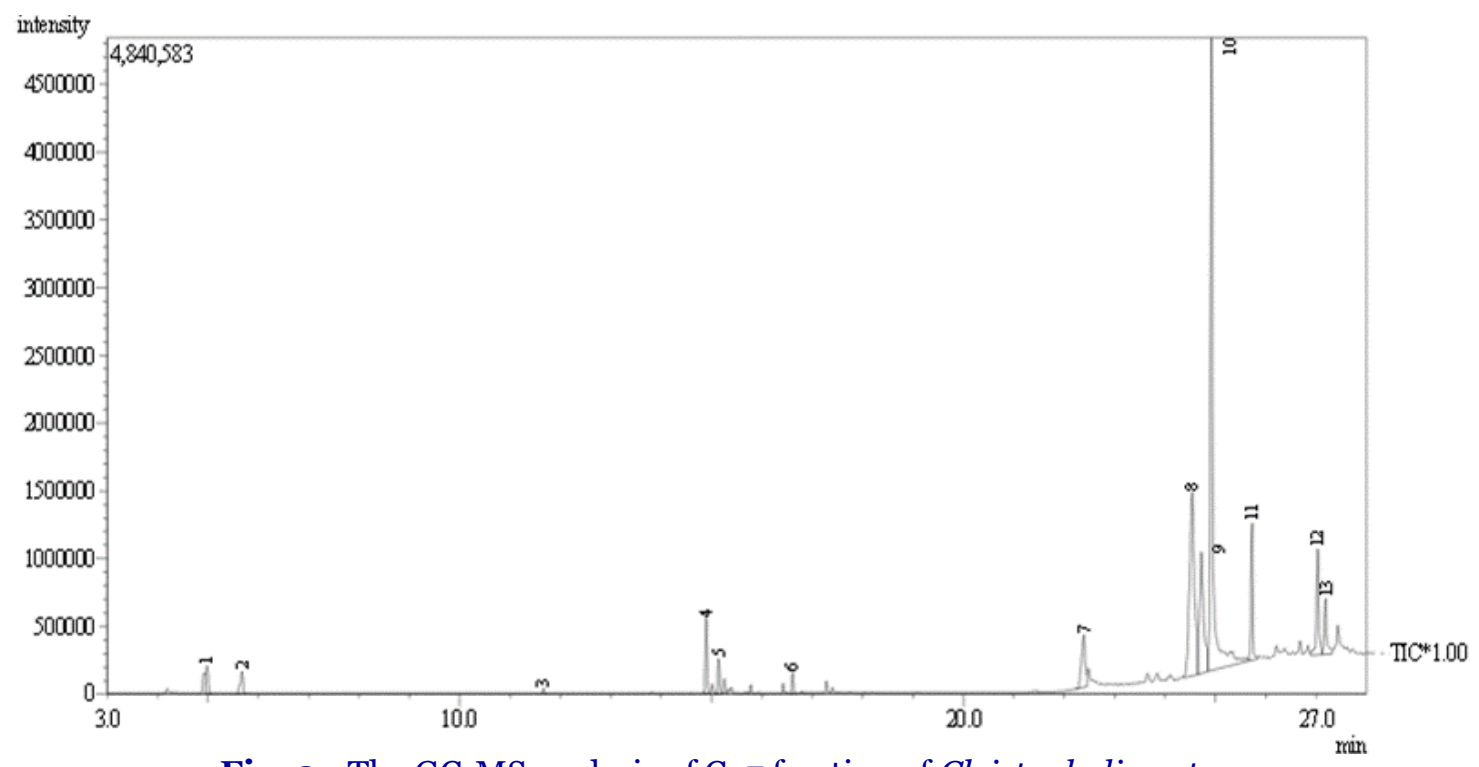

Fig. 2: The GC-MS analysis of $\mathrm{Cp} 7$ fraction of Cleistopholis patens. 
Table 5. Compounds identified in fraction $\mathrm{Cp} 7$ of Cleistopholis patens.

\begin{tabular}{|c|c|c|c|c|c|c|}
\hline Peak & R. time & Name of compound & Mol. formula & Mol. weight & Area & Chemical structure \\
\hline 1 & 4.988 & $\begin{array}{l}\text { Bicyclo[3.1.1]hept-2-ene, 2,6,6- } \\
\text { trimethyl-alpha.-Pinene }\end{array}$ & $\mathrm{C}_{10} \mathrm{H}_{16}$ & 136 & 1.65 & \\
\hline 2 & 5.680 & $\begin{array}{l}\text { Bicyclo[3.1.1]heptane, 6,6-dimethyl-2- } \\
\text { methylene- (beta.-Pinene) }\end{array}$ & $\mathrm{C}_{10} \mathrm{H} 16$ & 136 & 1.43 & \\
\hline 3 & 11.658 & $\begin{array}{l}\text { Cyclohexene,3-methyl-6-(1- } \\
\text { methylethylidene)- } \\
\text { (Terpinolene) }\end{array}$ & $\mathrm{C}_{10} \mathrm{H}_{16}$ & 136 & 0.22 & \\
\hline 4 & 14.895 & $\begin{array}{l}\text { 1,2,3,4,5,6,7,8-octahydro-1,4-dimethyl-7- } \\
\text { (1-methylethenyl)-, [1S- } \\
\text { (1.alpha.,4.alpha.,7.alpha.)]- } \\
\text { (Sesquiterpenes) }\end{array}$ & $\mathrm{C}_{15} \mathrm{H}_{24}$ & 204 & 3.23 & \\
\hline 5 & 15.140 & $\begin{array}{l}\text { 1,6-Cyclodecadiene, 1-methyl-5- } \\
\text { methylene-8-(1-methylethyl)-, [s-(E,E)]- } \\
\underline{\text { sesquiterpenes }}\end{array}$ & $\mathrm{C}_{15} \mathrm{H}_{24}$ & 204 & 1.53 & \\
\hline 6 & 16.611 & $\begin{array}{l}\text { 1H-Pyrazolo }[3,4-\mathrm{d}] \text { pyrimidine- } \\
\text { 4,6(5H,7H)-dione } \\
\text { (oxypurinol) }\end{array}$ & $\mathrm{C}_{5} \mathrm{H}_{4} \mathrm{~N}_{4} \mathrm{O}_{2}$ & 152 & 0.75 & \\
\hline 7 & 22.390 & $\begin{array}{l}\text { n-Hexadecanoic acid } \\
\text { (Palmitic acid) }\end{array}$ & $\mathrm{C}_{16} \mathrm{H}_{32} \mathrm{O}_{2}$ & 256 & 4.62 & \\
\hline 8 & 24.723 & $\begin{array}{l}\text { Octadecanoic acid } \\
\text { (Stearic acid) }\end{array}$ & $\mathrm{C}_{18} \mathrm{H}_{36} \mathrm{O}_{2}$ & 284 & 21.98 & \\
\hline 9 & 24.924 & $\begin{array}{l}\text { 2,6,10-Dodecatrien-1-ol, 3,7,11- } \\
\text { trimethyl- } \\
\text { (Farnesol) }\end{array}$ & $\mathrm{C}_{15} \mathrm{H}_{26} \mathrm{O}$ & 222 & 12.20 & \\
\hline 10 & 25.724 & $\begin{array}{l}\text { Hexadeca-2,6,10,14-tetraen-1-ol, } \\
\text { 3,7,11,16-tetramethyl-, (E,E,E) } \\
\text { (Geranylgeranoil) (Diterpenes) }\end{array}$ & $: \mathrm{C}_{20} \mathrm{H}_{34} \mathrm{O}$ & 290 & $37 \cdot 54$ & \\
\hline 11 & 27.184 & $\begin{array}{l}\text { Octadecanoic acid, 2-hydroxy-1,3- } \\
\text { propanediyl ester } \\
\text { (Alcoholic fatty acids) }\end{array}$ & $\mathrm{C}_{39} \mathrm{H}_{76} \mathrm{O}_{5}$ & 624 & $5 \cdot 36$ & \\
\hline 12 & 27.031 & $\begin{array}{l}\text { 9,12-Octadecadienoic acid (Z,Z)- } \\
\text { (diterpenoid) }\end{array}$ & $\mathrm{C}_{18} \mathrm{H}_{32} \mathrm{O}_{2}$ & 280 & 6.25 & \\
\hline
\end{tabular}




\section{Discussion}

Natural products, such as plant extract, either as pure compounds or as standardized extracts, provide unlimited opportunities for control of microbial growth owing to their chemical diversity. The result of the antibacterial susceptibility of the test bacteria presented a $70 \%$ susceptibility to the plant extract whereas a high degree of resistance was recorded for the standard antibiotics tested. Antibiotic resistance has been a major source of public health challenge. The systematic screening of plant-derived bioactive compounds as resistance modifying agents represents a potential approach to overcome bacterial resistance.

The MAR index of bacteria used in this work also showed a high rate of resistance to standard antibiotics. This implied that the test organisms were resistant to the antibiotics used. Multiple antibiotic resistance (MAR) in bacteria is most commonly associated with the presence of plasmids which contain one or more resistance genes, each encoding a single antibiotic resistance phenotype. High prevalence of multidrug resistance indicates a serious need for broadbased, local antimicrobial resistance surveillance and planning of effective interventions to reduce multidrug resistance in such pathogens (Osundiya et al., 2013).

Two principal drivers of resistance appear to be inadequate (or inappropriate) empirical antibiotic (Fish and Ohlinger, 2006) therapy and prolonged antibiotic use. The menace of antimicrobial resistance is particularly worrisome in developing countries like ours where there is a high burden of infectious disease with concomitant high rate of poverty which constrains the access to newer, more effective and (Okeke et al., 2005) conversely more expensive antimicrobial agents.

The comparative antibacterial activity of the crude extracts and the purified extract showed to a great extent the synergistic effect of the different phytochemicals that make up the plant. Yuan et al., (2017) opined that different components in a prescription exert a synergistic effect in such ways as acting on different targets or improving the solubility of active compounds, which constitute the pharmaceutical basis of traditional medicines.
The presence of different phytochemicals with different modes of action as observed by Rasoanaivo et al. (2011) contribute to high efficacy of crude plant materials as compared to purified fractions.

Reduced biological activity of purified fractions have been attributed by several authors to factors such as the poor quality of ethnopharmacological studies, plant material processing, preclinical laboratory protocols which are often very different from local practices, an inadequate fractionation process, degradation of active constituents during fractionation and poor biological models to demonstrate activities (Rasoanaivo et al., 2011).

Pure drugs that are isolated from plants may be chosen for their high activity against a human disease, but they have disadvantages. They rarely have the same degree of activity as the unrefined extract at comparable concentrations or dose of the active component (Wagner and Ulrich-Merzenich, 2009). This phenomenon is attributed to the absence of interacting substances present in the extract. Furthermore, many plants contain substances that inhibit multi-drug resistance (MDR). This may explain why crude extracts are often more effective than isolated constituents at an equivalent dose.

The plant Cleistopholis patens is rich in phytochemicals such as glycosides, steroids, phenol, tannin and saponin. These phytochemicals are suspected to be responsible for the activities of the plant extract against the array of bacterial tested against it. Essential oils are complex mixtures of volatile, lipophilic and odiferous substances from the secondary metabolism of plants. They are mainly composed of monoterpenes, sesquiterpenes and their oxygenated derivatives (alcohols, aldehydes, esters, ketones, phenols and oxides).

The chemical components of the plants identified in a GC-MS analysiscould be responsible for the antibacterial properties of the plant as indicated in the antibacterial test result. The analysis revealed predominantly essential oils, fatty acids, esters and terpenoids. Ouattara et al., (2018) in their work isolated several essential oils in the stem bark extract of C.patens including patchoulenone, $\beta$ pinene, bornyl acetate, $\alpha$-pinene, juvenile 
hormone III, and $\beta$-elemol among others. Several essential oils have been used as therapeutic agents since ancient times, and some of them have been scientifically proven to possess medicinal properties, including anti-inflammatory (Koudou et al., 2005), antiviral (Loizzoa et al., 2007), antitumor (M'Barek, 2007), cytotoxic (Zarai et al., 2011) and antimicrobial activities (Alviano et al., 2007).

Natural phytochemicals including flavonoid and phenolic compounds as well as fatty acids are major bioactive compounds known to be beneficial against many diseases and have been reported to possess a wide range of biological effects like antioxidant and antibacterial activities (Sofowora, 1996). C.patens is found to be rich in fatty acids including stearic acids, lenolic acids and esters which occur in copious amount in the plant and are known to have medicinal properties as antimicrobial, antifungal agents (Krishnaveni et al., 2014). The biological activities of free fatty acids have roles in host defenses against potential opportunistic or pathogenic microorganisms. An important aspect of this is growth inhibition or the quick destruction of bacteria (Desbois and Smith, 2010).

Sesquiterpenes are also present in extract. Sesquiterpenes are known to have antiinflammatory (Jeenaet al 2013)and have bactericidal properties (Ishnava et al 2013). 9,12Octadecadienoic acid (Z,Z)- a diterpenoid also present is used as anti-inflammatory, hypocholesterolemic, cancer preventive, hepatoprotective, nematicide, insectifuge(cide), antihistaminic, antieczemic, antiacne, 5- $\alpha$ reductase inhibitor, antiandrogenic, antiarthritic, anti-coronary, antimicrobial (Adeoye-Isijola et al., 2018).

\section{Conclusion}

The essential oils extracted from this plant possess strong antimicrobial activity against various bacterial pathogens. The reactivity of essential oils depends upon the nature of their functional groups and orientation. Essential oils may disrupt the cell membrane of the targeted pathogens by increasing membrane permeability, inducing leakage of vital intracellular constituents, and interrupting the cellular metabolism and enzyme kinetics of the targeted pathogens. The result of this study showed plant Cleistopholis patens is rich in compounds that are responsible for the biological activities of the plant. The phytochemicals observed in this plant can be subjected to further studies to identify their mode of action, toxicity and spectrum of activity. However, the plant is a good candidate for drug production.

\section{Conflict of interest statement}

Authors declare that they have no conflict of interest.

\section{References}

Adeoye-Isijola, M.O., Olajuyigbe, O.O., Jonathan, S.G, Copoosamy, R.M., 2018. Bioactive compounds in ethanol extract of Lentinus squarrosulus MONT - A Nigerian medicinal macrofungus. Afr. J. Trad. Compl. Alt. Med. 15 (2), 42-50.

Atuhe. G., 2010. The Ecological Status of Cleistopholis patens in Budongo Forest Reserve, Uganda. July 2010.

Alviano D.S., Alviano C.S., 2009. Plant extracts: Search for new alternatives to treat microbial diseases. Curr. Issues Pharmaceut. Biotechnol. 10, 106-121.

Bauer, A. W., Kirby, W. M. N., Sherris, J. C., Turk, M., 1986. Antibiotic susceptibility testing by a standardized single disk method. Amer. J. Clin. Pathol. 45, 493-496.

Banso, A., Ngbede, J.E., 2006. Phytochemical screening and in vitro antifungal properties of Fagara zanthoxyloides. J. Agric. Food Environ. 4(3\&4), 8-9.

Baser, K. H. C., Buchbauer, G., 2010. Handbook of Essential oils. Science, Technology and Applications. CRC Press, Boca Raton, London, New York.

Blainski, A., Lopes, C.G., de Mello, J.C., 2013. Application and analysis of the folin ciocalteu method for the determination of the total phenolic content from Limonium brasiliense L. Molecules. 18, 6852-6865.

Burkil, H. M., 2004. The useful plants of west tropical Africa. First Edition. Royal Botanic Gardens, Kew, Richmond, United Kingdom. pp.25-28.

Boham, B.A., Kocipai, A. R., 1994. Flavonoids and condensed tannins from leaves of Hawaiian 
Vaccinium vaticulatum and $V$. calycinium. Pacific Sci. 48, 458-463.

Cheesebrough, M., 2000. District laboratory practice in tropical countries. Part 2. Cambridge University Press. U.K. pp.62-70.

Cosa, P., Vlietinck, A. J., Berghe, D. V., Maes, L., 2006. Anti-infective potential of natural products: How to develop a stronger in vitro proof-of-concept. J. Ethnopharmacol. 106, 290-302.

Desbois, A. P., Smith, V. J., 2010. Antibacterial free fatty acids: activities, mechanisms of action and biotechnological potential.Appl. Microbiol. Biotechnol. 85(6), 1629-1642.

Evans, W.C., 2009. Trease and Evans Pharmacognosy $\left(16^{\text {th }}\right.$ Edn.), Edinburg, Saunders, Elsivier. 614p.

Fish D. N., Ohlinger, M. J., 2006. Antimicrobial resistance: factors and outcomes. Crit. Care Clinic. 22(2), 291-231.

Ishnava, K. B., Chauhan, J. B., Barad, M. B., 2013. Anticariogenic and phytochemical evaluation of Eucalyptus globules Labill. Saudi J. Biol. Sci. 20(1), 69-74.

Jeena, K., Liju, V. B., Kuttan, R., 2013. Antioxidant, anti-inflammatory and antinociceptive activities of essential oil from ginger. Indian J. Physiol. 57, 51-62.

Harbone, J. B., 1984. Phytochemical Methods- A Guide to Modern Techniques of Plant Analysis ( $2^{\text {nd }}$ Ed). Chapman and Hall, London. 30op.

Koudou, J., Abena, A. A., Ngaissona, P., Bessière J. M., 2005. Chemical composition and pharmacological activity of essential oil of Canarium schweinfurthii. Fitoterapia. 76, 700703.

Krishnaveni, M., Dhanalakshmi, R., Nandhini, N., 2014. GC-MS analysis of phytochemicals, fatty acid profile, antimicrobial activity of Gossypium seeds. Int. J. Pharmaceut. Sci. Rev. Res. 7(1), 273-278.

Krumperman, P. H., 1983. Multiple antibiotic resistance indexing of Escherichia coli to indentify high-risk sources of fecal contamination of foods. Appl. Environ. Microbiol. 46, 165-170.

Odebiyi, O. O., Sofowora, E. A., 2005. Phytochemical screening of Nigerian medicinal plants IV. Lloydia. 41, 234-248.

Okeke, I. N, Laxminarayan, R., Bhutta, Z. A., Duse, A. G., Jenkins, P., O'Brien, T. F., 2005. Antimicrobial resistance in developing countries. Part 1: Recent trends and current status. Lancet Infect. Dis. 5(8), 481-493.

Osundiya, O. O., Oladele, R. O., Oduyebo, O. O., 2013. Multiple antibiotic resistance (MAR) indices of Pseudomonas and Klebsiella species isolates in Lagos University Teaching Hospital. Afr. J. Clin. Exp. Microbiol. 14(3), 164-168.

Dutra, R. C., Pittella, F., Dittz, D., Marcon, R., Pimenta, D. S., Lopes, M. T., Raposo, N. R., 2012. Chemical composition and cytotoxicity activity of the essential oil of Pterodon emarginatus. Rev. Bras. Farmacogn. 22(5), 971-978.

Rasoanaivo, P., Wright, C. W., Willcox, M. L., Gilbert, B., 2011. Whole plant extracts versus single compounds for the treatment of malaria: Synergy and positive interactions. Malaria J. 10 (Suppl. 1), S4.

Ouattara, Z. A., Yapi, T. A., Békro, Y. A., Mamyrbékova-Békro, A. J., Paoli, M., Tomi, P., Casanova, J., Bighelli, A., Tomi, F., 2018. Composition and chemical variability of root bark oil from Ivoirian Cleistopholis patens. Natural Prod. Commun. 13(6), 767770.

Loizzoa, M. R., Saabb, A., Tundisa, R., Stattia, G. A., Lamprontic, I., Menichinia, F., Gambarid, R., Cinatle, J., Doer, H. W., 2008. Phytochemical analysis and in vitro evaluation of the biological activity against herpes simplex virus type 1 (HSV-1) of Cedrus libani A. Rich. Phytomedicine. 15, 79-83.

M'Barek, L. A., Ait Mouse, H., Jaâfari, A., Aboufatima, R., Benharref, A., Kamal, M., Bénard, J., El Abbadi, N., Bensalah, M., Gamouh, A., 2007. Cytotoxic effect of essential oil of thyme (Thymus broussonettii) on the IGR-OV1 tumor cells resistant to chemotherapy. Braz. J. Med. Biol. Res. 40, 1537-1544.

Sofowora, A., 1996. Research on medicinal plants and traditional medicine in Africa. J. Alt. Compl. Med. 2(3), 365-372.

Wagner, H., Ulrich-Merzenich, G., 2009. Synergy research: Approaching a new generation of phytopharmaceuticals. Phytomedicine. 16, 97110.

Weigand, I., Hilpert, K., Hancock, R. E. W. 2008. Agar broth dilution methods to determine the MIC of antimicrobial substances. Nature Protocol. 3(2), 163-175.

Yuan, H., Ma, Q., Heying Cui, H., Liu, G., Zhao, X., 
Li, W., Piao, G., 2017. How can synergism of traditional medicines benefit from network pharmacology? Molecules. 22, 1135-1154.

Zarai, Z., Kadri, A., Chobba, I. B., Mansour, R.B., Bekir, A., Mejdoub, H., Gharsalla, N., 2011. The in-vitro evaluation of antibacterial, antifungal and cytotoxic properties of Marrubium vulgare L. essential oil grown in Tunisia. Lipids Health Dis. 10, 161. Doi: 10.1186/1476511X-10-161.

\section{How to cite this article:}

Daniels, A.O., Temikotan, T., Fadairo, F.K., 2020. Antibacterial activity, phytochemicals and essential oils in ethyl acetate extract of Cleistopholis patens. Int. J. Curr. Res. Biosci. Plant Biol. 7(3), 26-38.

doi: https://doi.org/10.20546/ijcrbp.2020.703.003 